\title{
Trindade e Moral Sexual A nomeação de Deus nas encíclicas que tratam do tema da sexualidade, entre o pontificado de Pio XI e Bento XVI
}

\author{
Orientador: Maria Clara Lucchetti Bingemer \\ Mestrando: Sergio Gonçalves Mendes \\ Área de Concentração: Teologia Sistemático-Pastoral \\ Linha de Pesquisa: Religião e Modernidade
}

A partir do Concílio Vaticano II muitos teólogos se dedicaram à tarefa de resgate do significado da revelação trinitária de Deus para a vida cristã. A teologia moral, em particular, recebeu diversas contribuições. De forma especial o desenvolvimento da Cristologia e da Pneumatologia contribuíram para a compreensão de novas implicações éticas do mistério de Deus. Por essa razão, o presente trabalho visa, em primeiro lugar, refletir sobre a importância da Trindade para a Moral Sexual. Nesse aspecto, uma rica possibilidade de renovação da Moral Sexual surge com a diversidade de modelos morais associados a cada pessoa trinitária, tais como o de imitação do Pai, o da filiação, o da fraternidade-sororidade, o da solicitude maternal, o da aliança, o de imitação e seguimento de Cristo, o da nova lei, o da vida no Espírito, o da santificação, etc. Em segundo lugar, considerando as principais encíclicas que tratam do tema da sexualidade, a saber, Arcanum Divinae Sapientiae (Leão XIII), Casti Connubii (Pio XI), Humanae Vitae (Paulo VI), Evangelium Vitae (João Paulo II) e Deus caritas est (Bento XVI), buscamos responder à questão da importância dada à Trindade pelos pontífices nesses documentos. Para isso, nos dedicamos a uma rigorosa análise da nomeação de Deus em cada uma das citadas encíclicas. Por fim, constatamos, que apesar dos significativos avanços, o discurso magisterial acerca da sexualidade ainda carece de uma articulação trinitária. E a partir dessa constatação, apresentamos algumas perspectivas que se abririam a uma moral sexual mais trinitariamente elaborada.

Palavras-chave: Moral Sexual; Trindade; Teologia Dogmática. 